\title{
The Renminbi in Ordinary Economies: A Demand-Side Study of Currency Globalization
}

\author{
Hyoung-kyu Chey \\ National Graduate Institute for Policy Studies (GRIPS)
}

January 2015

This is the pre-peer-reviewed version of the following article: Hyoung-kyu Chey, "Renminbi in Ordinary Economies: A Demand-side Study of Currency Globalization," China \& World Economy, volume 23, issue 3, pages 1-21, May/June 2015, which has been published in final form at https://onlinelibrary.wiley.com/doi/10.1111/cwe.12111. 


\begin{abstract}
Most studies of renminbi internationalization focus mainly on the supply side, by examining China's own economic and political conditions related to it. This study in contrast addresses the demand-side of renminbi internationalization, by providing an indepth analysis of renminbi use in ordinary foreign economies from both economic and political perspectives, with a particular focus on South Korea, China's next-door neighbor. It finds that sustainable indigenous market forces facilitating renminbi use in South Korea remain weak, despite the country's close economic ties with China. This research also shows, however, that the Korean government has itself recently been able, through its policy measures, to generate new domestic vested interests supporting greater use of the renminbi. These findings ultimately highlight the significant impact on the internationalization of a currency of the politics in the foreign countries using it.
\end{abstract}

Key words: currency internationalization, global currency, international currency, renminbi, yuan

JEL codes: E42, F02, F33, F50 


\section{Introduction}

Since the outbreak of the 2008-09 global financial crisis the Chinese authorities have employed a variety of policy measures to actively promote internationalization of their own currency, the renminbi (RMB), in pursuit of multiple goals including the reduction of China's reliance on the US dollar (henceforth, the dollar), the strengthening of its international influence and the acceleration of its domestic financial reforms. ${ }^{1}$ As a result, although its absolute level is still quite low global use of the RMB has grown remarkably within just a few years, with the rank of the RMB's share in total global payments for instance jumping from 20th in the world in January 2012 to seventh in September 2014.

Along with this impressive progress in RMB internationalization, research on the subject has also exploded in recent years. Most studies share two common elements. In analyzing the factors that affect RMB internationalization they tend to provide supply-side analyses, focusing on China's own economic and political conditions. In examining the level of RMB internationalization, meanwhile, they tend to rely mainly on either the aggregate data of RMB use at the global level or the data of RMB use in Hong Kong.

Such analysis of RMB internationalization is undoubtedly necessary and important. It has a critical limitation, however, in that it pays little attention to the actual uses of the

\footnotetext{
${ }^{1}$ The Chinese authorities have not officially announced the goals of RMB internationalization. A good number of studies have however attempted to identify them. See, for example, Kirshner (2014), Mallaby and Wethington (2012) and Yu (2014). Meanwhile, for Chinese government policies to promote RMB internationalization, see Eichengreen and Kawai (2014), Subacchi (2013) and Yu (2014).
} 
RMB in foreign economies, especially ordinary foreign economies that, unlike Hong Kong for example, have neither unique political relations with China nor international financial centers. In fact, the supply-side analysis of RMB internationalization usually addresses the costs and benefits of using the RMB from the Chinese perspective only, rather than from foreign users' perspectives. This is a serious shortcoming, however, as RMB internationalization ultimately requires the use of the RMB by non-Chinese. The heavy reliance on the aggregate data of global RMB use or the data on RMB use in Hong Kong is also problematic, since it hinders analysis of the uses of the RMB in individual foreign economies, which vary across countries. Moreover, the dynamics of RMB use in ordinary economies may differ from those in international financial centers or in economies with special political relations with China, while a consequential level of RMB internationalization is unlikely to be achieved without growth in RMB use in such ordinary economies. It is therefore necessary to explore the uses of the RMB in ordinary foreign economies, in order to better understand the factors affecting RMB internationalizationand, going further, currency internationalization in general — and to better forecast the future of RMB internationalization.

In this context, this study provides a demand-side analysis of RMB internationalization by addressing the use of the RMB in ordinary foreign economies, with the specific focus being the case of South Korea (henceforth, Korea). Its primary goal is to draw valuable insights from its in-depth analysis of the Korean case for future use in the analysis of RMB internationalization as well as currency internationalization in general, rather than to develop a formal theory of currency internationalization or to rigorously test competing 
hypotheses. This research is thus close to a hypothesis-generating study. And it is also distinct in that it offers a comprehensive study of RMB use in the case country by analyzing both the economic and the political dynamics surrounding it.

This research argues that strong indigenous market forces supporting sustainable use of the RMB have not emerged yet in Korea, even despite its close economic relations with China. It also holds, however, that political forces are likely to boost RMB use in the country. More specifically, it argues that the Korean government has effectively implemented the infrastructures essential for simulating RMB use even in the absence of strong private sector demand for them and, going further, that it has been able to generate the emergence of new domestic vested interests supporting greater use of the RMB, by creating through its policy measures novel incentives for them to favor it. These findings ultimately suggest that, at least in the early stage of internationalization of a currency, the growth of its use in ordinary foreign economies is likely to be significantly affected by the domestic politics involving those economies themselves, as well as by economic and political conditions in the issuing country.

Korea is selected as the primary research case in view of the considerable advantages it offers for the analysis of RMB internationalization. First, the geographical area in which RMB internationalization is most likely to develop in its initial stage is Asia (it is in fact widely suspected that the Chinese authorities aim to develop the RMB into a regional currency in Asia first), and Korea is one of the major countries in that region as well as China's next-door neighbor. Korea moreover has strong economic ties with China, as will be discussed in detail later. In these circumstances, the use of the RMB in Korea may have 
significant implications for the future of RMB internationalization, with a high level of RMB use in that country suggesting a positive future for it and a low level implying the opposite. In addition, this study's focus on the case of a single country enables it to conduct a more in-depth analysis of that case. Indeed, this research examines the use of the RMB in various areas, including for trade settlement, as private investment assets and as foreign exchange reserves, thereby providing a balanced and systematic assessment of RMB use in Korea.

In analyzing RMB use in Korea, this study adopts mainly qualitative analysis, including the investigation of government documents and in-depth interviews with policymakers and experts in various relevant institutes such as the Ministry of Strategy and Finance (MOSF), the Bank of Korea (BOK), the Korea Trade-Investment Promotion Agency (KOTRA), the Korea International Trade Association (KITA), the Korea Center for International Finance (KCIF), the Korea Institute for International Economic Policy (KIEP), the Korea Institute of Finance (KIF) and the Korea Capital Market Institute (KCMI), as well as major private banks both domestic and foreign-owned.

The remainder of this paper is organized as follows. The next section highlights the need for a demand-side study of RMB internationalization. The following two sections address, respectively, the economic and the political aspects of RMB use in Korea. The final section concludes, discussing this study's major implications.

\section{Need for demand-side analysis}


The literature on RMB internationalization deals primarily with its feasibility, adopting various methods and offering varying conclusions. Some studies employ quantitative methods based on Chinn and Frankel's (2008) analysis of the internationalization of the euro, using the economic conditions of the country issuing a currency — such as its shares in global output and trade, its financial market development, its price level and network externalities - as the major determinants of the degree of that currency's internationalization, in particular as a reserve currency. One good example is Lee (2014b), which forecasts that the share of the RMB in the world's reserves will rise to around 3 to 12 percent by 2035 .

There are also a good number of studies using more qualitative methods. Similar to Lee (2014b) mentioned above, a majority of them - including Chen and Cheung (2011), Cohen (2012; 2014), Dobson and Masson (2009), Park (2010), Subacchi (2013), Subramanian (2011a; 2011b), Wu et al. (2010) and Yu (2014) —address mainly the economic conditions of China as the key factors affecting RMB internationalization. Some studies meanwhile pay more attention to the political conditions surrounding RMB internationalization. For example, Chey (2013) examines China's international power as a crucial determinant of RMB internationalization, while Helleiner and Malkin (2012) analyze the preferences of domestic actors in China with regard to RMB internationalization. Eichengreen (2013) and Eichengreen and Kawai (2014) meanwhile draw attention to the impacts on RMB internationalization of China's domestic political institutions, such as its authoritarian political regime and the weak independence of its central bank, the People's Bank of China (PBOC). In general, these qualitative studies tend to be more cautious about the feasibility 
of rapid RMB internationalization, although there are some more positive views such as those of Campanella (2014), Kirshner (2014), Subacchi (2013) and Subramanian (2011a; 2011b).

Most of the existing studies, however, irrespective of their differences in methodologies or arguments, share two common characteristics. First, in addressing the factors that influence the internationalization of the RMB, a majority of them focus largely on the economic or political conditions of China itself, the issuer of the RMB. In other words, they tend to provide supply-side analyses of RMB internationalization. Second, in analyzing the degree of RMB internationalization, most studies do not consider the uses of the RMB in individual foreign economies, especially ordinary ones that have neither special political relations with China nor international financial centers. They instead rely mainly on either the aggregate data at the global level (such as the RMB's share in total global payments or in the world's reserves) or the data of RMB use in Hong Kong. These two characteristics in the studies of RMB internationalization are in fact quite common in the literature on currency internationalization in general, as well. ${ }^{2}$

Such analysis of RMB internationalization — and also currency internationalization in general - is obviously necessary and desirable in several respects. It has a notable limitation, however, in that it largely neglects the demand-side, that is, how individual foreign economies actually perceive and respond to RMB internationalization and the Chinese government's policies promoting it. The levels of RMB use differ across countries and, further, across sectors within the same country, and are likely to be affected by political and

\footnotetext{
${ }^{2}$ For a comprehensive review of the literature on currency internationalization, see Chey $(2012 ; 2014)$.
} 
economic factors in the countries themselves, as well as those in China. An analysis concentrating on the Chinese side alone cannot explain such differences in foreign uses of the RMB. The reliance on the aggregate data of RMB use at the global level, or on the data of that in Hong Kong, may meanwhile provide an inflated or distorted assessment of RMB internationalization, given that Hong Kong accounts for the majority of total global RMB use and, moreover, that a majority of those using the RMB in Hong Kong are actually from the mainland. ${ }^{3}$ The appropriateness of treating Hong Kong as a "foreign" region in analyzing "internationalization" of the RMB is in fact not clear, since despite its administrative independence the city is essentially a part of China.

It is thus necessary to analyze the uses of the RMB in individual foreign economies in order to better understand the determinants of RMB internationalization — and of currency internationalization in general — and to in turn better forecast its future. And this requires examination of the costs and benefits of RMB use from foreigners' perspectives, while the supply-side analysis tends in contrast to consider the Chinese perspective only in that regard. ${ }^{4}$ To be sure, there are a few studies that do give attention to RMB use in foreign economies, even though most of them do not highlight this important aspect. They include mainly those examining the co-movements between the RMB and other currencies, based

\footnotetext{
${ }^{3}$ For example, although Hong Kong's share in global use of the RMB has declined to some extent recently, about 74 percent of the world's RMB payments in December 2013 were still being made there (SWIFT, 2014). In the meantime, Chinese state-owned banks and large Chinese commercial banks accounted for more than 55 percent of all dim sum bonds issued in 2012 and 2013 (Song, 2013).

${ }^{4}$ For a discussion of the costs and benefits of RMB internationalization for China, see Chey (2013: 350-51).
} 
mostly on the Frankel and Wei (1994) method. ${ }^{5}$ These studies also have significant drawbacks, however, in concentrating merely on one monetary function of an international currency — that is, on its use as a reference currency for exchange rate pegging - while overlooking its other important monetary functions such as its uses as a trade invoicing and settlement currency, an investment asset or a foreign reserve currency. ${ }^{6}$ Liao and McDowell (forthcoming) meanwhile provide an analysis of the countries that have established bilateral local currency swap arrangements with China. But such currency swap arrangements are actually closer to means for promoting RMB internationalization, rather than being indicative of RMB internationalization per se.

In an attempt to fill in the gaps left by such critical shortcomings in the literature, this study provides a demand-side analysis of RMB internationalization, focusing on the use of the RMB in the ordinary foreign economy of Korea. It examines the use of the RMB in Korea and addresses the factors that affect it, analyzing both economic and political ones. Its findings are expected to provide valuable insights as to how RMB internationalization is likely to proceed in the future, thus ultimately dealing with the salient question of how the supply-side efforts by China to promote RMB internationalization have actually been received by ordinary foreign economies. Given that most studies of currency

\footnotetext{
${ }^{5}$ A majority of these studies - including Fratzscher and Mehl (2011), Ito (2010) and Subramanian and Kessler (2012) — make bold claims that a RMB bloc has already been formed in East Asia, suggesting that the international monetary system has now been transformed into a multipolar currency one. A few studies such as Kawai and Pontines (2014), however, foresee continuing dominance by the dollar as the primary anchor currency in that region.

${ }^{6}$ For the various monetary functions of international currencies, see Chey $(2012 ; 2014)$.
} 
internationalization tend to adopt supply-side analyses, this demand-side research is also likely to contribute significantly to the literature on currency internationalization in general, and its findings may be applicable to analysis of the internationalizations of other currencies as well.

\section{Economics of RMB internationalization}

This section analyzes the economic aspects of RMB use in Korea, addressing first the trade and then the financial sector. It shows that strong market forces favoring RMB use have not yet appeared in the country, even despite China's enthusiastic drive for RMB internationalization as well as the close economic relations between the two countries.

\section{Obstacles to RMB use in trade}

To look at the real economy side first, the use of the RMB as a trade settlement currency in Korea remains marginal. As Table 1 shows, the share of total Korean exports settled in the RMB amounted to a mere 0.4 percent during the third quarter of 2014 . It was also only 1.6 percent even for exports to China during that period, while the dollar accounted for 95.6 percent. The share in Korean exports to China settled in the Korean won was actually slightly higher in that period, at $1.7 \%$. The import side is even less propitious. The proportion of total Korean imports settled in the RMB reached a mere 0.2 percent in the same period, while the share for imports from China itself also recorded just 1.0 percent 
(although that was a historical high), compared to the 95.4 percent share of the dollar. Here, again, use of the Korean won for settlement of Chinese imports was higher during the period, reaching 1.4 percent. $^{7}$ It should be emphasized in addition that Korea's use of the RMB in trade settlement has involved almost exclusively trade with China, which accounts for 99 percent of its total RMB-settled trade.

Table 1. Shares of the US Dollar and the RMB in Total Korean Trade Settlement, 2007 to Q3 2014 $(\%)$

\begin{tabular}{lllllllll}
\hline 2007 & 2008 & 2009 & 2010 & 2011 & 2012 & 2013 & Q3 \\
& & & & & & & 2014 \\
\hline
\end{tabular}

Exports

To the world

$\begin{array}{lllllllll}\text { Dollar } & 82.2 & 84.3 & 85.4 & 85.9 & 85.7 & 85.1 & 85.2 & 86.2\end{array}$

$\begin{array}{lllllllll}\text { RMB } & 0.0 & 0.0 & 0.0 & 0.1 & 0.1 & 0.2 & 0.4 & 0.4\end{array}$

To China

$\begin{array}{lllllllll}\text { Dollar } & 97.5 & 97.3 & 97.3 & 97.3 & 96.9 & 96.7 & 95.3 & 95.6\end{array}$

$\begin{array}{lllllllll}\text { RMB } & 0.0 & 0.0 & 0.0 & 0.2 & 0.6 & 1.0 & 1.6 & 1.6\end{array}$

$\underline{\text { Imports }}$

\footnotetext{
${ }^{7}$ In fact, the volume of Korean trade settled in the RMB has grown considerably. This rise in RMB use for trade settlement is illusory, however, as it began from a very low base of almost zero.
} 
From the world

$\begin{array}{lrrrrrrrr}\text { Dollar } & 80.7 & 82.0 & 80.1 & 81.3 & 82.5 & 83.9 & 84.2 & 84.5 \\ \text { RMB } & 0.0 & 0.0 & 0.0 & 0.0 & 0.0 & 0.0 & 0.1 & 0.2\end{array}$

From China

$\begin{array}{lllllllll}\text { Dollar } & 95.0 & 94.5 & 93.8 & 95.3 & 94.1 & 94.8 & 94.9 & 95.4\end{array}$

$\begin{array}{lllllllll}\text { RMB } & 0.0 & 0.1 & 0.1 & 0.1 & 0.2 & 0.3 & 0.7 & 1.0\end{array}$

Source: The Bank of Korea

The BOK established a bilateral local currency swap with the PBOC in December 2008 - becoming the PBOC's first partner for its bilateral RMB-local currency swap arrangements - and in December 2012 then introduced a system for using the swap funds to provide local currency liquidity for trade settlement. Although this system offers a stable RMB liquidity pipeline for Korean firms, ${ }^{8}$ however, Korean firms have hardly utilized the RMB lending available to them through it.

This minimal use of the RMB for trade settlement in Korea is in fact a bit surprising. As is widely known, the promotion of RMB trade settlement is one of the two major pillars of the Chinese government's strategies to facilitate RMB internationalization, together with the development of offshore RMB markets. ${ }^{9}$ Korea has strong trade ties with China, moreover; it became China's fourth largest trading partner in 2013, while China is Korea's

\footnotetext{
${ }^{8}$ The BOK established the swap arrangement during the global financial crisis, primarily as a means for crisis prevention. Its initial duration was three years, but it has since been renewed twice so that the current expiration date is October 2017. Its size was also doubled in 2011, from the initial 180 billion renminbi/38 trillion won to 360 billion renminbi/64 trillion won.

${ }^{9}$ See Eichengreen and Kawai (2014), Subacchi (2013) and Yu (2014).
} 
largest trading partner in terms of both exports and imports, accounting for 25 percent of its total exports and 17 percent of its imports in October 2014. Korea has also recorded large trade surpluses against China over the past years, especially since 2008 and reaching USD 63 billion in 2013, implying the strong potential for Korea to accumulate and, accordingly, use the RMB. The persistent sluggishness in RMB trade settlement in Korea even despite these favorable conditions suggests strongly that market forces favorable to RMB trade settlement there remain quite weak.

What then explains this surprisingly low level of RMB use in trade settlement in Korea? One problem is the limited RMB investment opportunities in the country. In fact, while RMB deposits had until not long ago been the only meaningful investment option, Korean banks have typically charged high exchange commissions of around 2 to 3 percent for RMB deposits, and RMB depositors have as a result actually had to bear losses at most banks, reducing their incentives to use the RMB. Yet, as will be examined later, Korean financial institutions' interest in the RMB business has grown significantly of late. The problem of the limited RMB investment opportunities may thus be mitigated to some extent in the future, although this will still take time.

There is, however, another fundamental obstacle to the use of the RMB in trade settlement in Korea: the high transaction costs, particularly in comparison with those for use of the dollar. When Korean exporters use RMB letters of credit (L/Cs), for instance, they must pay far higher exchange rate commissions than when using dollar L/Cs. In September 2014, in fact, the commissions for three-month maturity L/Cs were 2.7 percent for dollar L/Cs compared to 5.7 percent for the RMB (MOSF, 2014b). Moreover, when 
Korean firms use the RMB for trade settlement with their Chinese trade partners, they usually have to handle double exchange risks, both for the RMB and for the dollar, as many still have to continue using the dollar for their other trading partners. Firms also have to establish operating systems for RMB settlement, which are costly. In short, although RMB trade settlement benefits Chinese firms substantially, by reducing their own exchange rate risks and foreign exchange-related operating costs, it does not generate meaningful benefits to Korean firms but instead generally adds new risks and increases their operating costs. Given that trading companies' choices of trade settlement currencies are determined largely by transaction-related rather than speculative motives, high transaction costs are likely to seriously hinder use of the RMB in trade settlement. ${ }^{10}$

Many Chinese exporters are in fact even willing to offer discounts, of around 3 to 5 percent, to foreign importers agreeing to use the RMB for settlement, as these exporters can then reduce their exchange rate risks and various operational costs (Euromoney, 2013; Lee, 2012). ${ }^{11}$ Yet, as indicated, such discounts have failed to provide incentives strong enough to

\footnotetext{
${ }^{10}$ In many cases, in fact, even Chinese firms themselves prefer dollar settlement, in part because they import intermediary goods from Korea and export the final products to markets such as the United States (author interview with Choi PilSoo, Head, China Research Team, KIEP, September 17, 2013, Seoul).

${ }^{11}$ There are some Chinese firms, particularly importers, that request RMB trade settlement. However, most Chinese requests for RMB settlement are not forceful or strong, as the Chinese firms themselves are well aware of the underdevelopment of the basic infrastructures for RMB use (author interviews with Kim Woong Ryeol; and with Lee Bong-Geol, Chief Researcher, Strategic Market Research Team, Institute for International Trade, KITA, September 16, 2013, Seoul).
} 
entice Korean firms to increase their RMB use, implying in turn that the costs to them stemming from RMB use are substantial.

A significant decline in the transactions costs of RMB use in trade settlement, especially in comparison with those of dollar use, is likely to emerge only after RMB internationalization reaches a consequential level, as that will require a substantial maturing of the RMB financial markets. It should be stressed in this regard that, even though the share of China's trade settled in the RMB has risen to about 25 percent, more than 80 percent of China's RMB trade settlement is in fact with Hong Kong, with all other "real" foreign economies together accounting for the remaining 20 percent only (Eichengreen and Kawai, 2014: 5). ${ }^{12}$

\section{Fragile foundation of RMB use in finance}

The situation of RMB use in the Korean financial sector had until recently not differed much from that in the trade sector. For example, while RMB deposits were the only available investment product the share in total foreign currency deposits of those in RMB had remained below 1 percent until August 2013, as shown in Figure 1. Most Korean financial institutions had in fact not been much interested in the RMB business. Their low

\footnotetext{
${ }^{12}$ Moreover, some Chinese companies have even exaggerated the values of their exports to Hong Kong, as shown in the USD 13.5 billion gap in October 2014 between the Chinese mainland exports to Hong Kong reported by China and that city's report of its imports from the mainland (Price, 2014).
} 
interest had been due in part to their shortages of professional expertise in the business. ${ }^{13} \mathrm{It}$ had also, however, been related to the more fundamental problem of their low competitiveness in the RMB business vis-à-vis Chinese and global financial institutions, stemming partly from their highly restricted access to the Chinese mainland financial markets. As a result, many Korean banks had tended to conduct RMB businesses mainly as parts of their marketing activities, rather than in accordance with RMB business strategies per se. ${ }^{14}$

Likewise, although the BOK has begun to hold RMB-denominated assets by participating in the Qualified Foreign Institutional Investor (QFII) scheme-which allows licensed foreign investors to invest in mainland securities and fixed incomes by switching dollars into RMB - and in the China interbank bond market (CIBM), since December 2011 and April 2012 respectively, the amounts involved have been extremely trivial. The BOK's QFII quota is USD 600 million, and its investment in the CIBM amounts to RMB 20 billion (USD 3.2 billion). This together accounts for around only 1 percent of the BOK's total foreign exchange reserves.

\footnotetext{
${ }^{13}$ Author interview with An Yu Hua, Research Fellow, International Finance Division, KCMI, September 11, 2013, Seoul.

${ }^{14}$ Author interviews with Lee Chi Hun, Deputy Director, Research and Analysis Office, KCIF, Seoul, September 6, 2013; Kim Woong Ryeol, Deputy General Manager, Woori Bank Samsungdong Branch (former Deputy General Manager, Foreign Exchange Business Department), September 12, 2013, Seoul; and Kim Dan Joo, Senior General Manager, Transaction Banking, Standard Chartered Bank Korea, September 25, 2013, Seoul.
} 
Yet, since the autumn of 2013 a remarkable change in RMB use in the Korean financial market has emerged. As shown in Figure 1, the volume of RMB deposits has grown suddenly and dramatically since that time, with the RMB's share in total foreign currency deposits rising to a record high of 33 percent in October 2014, while the corresponding figure for the dollar has dropped to 58 percent.

Figure 1. Shares of the US Dollar and the RMB in Total Foreign Currency Deposits by Residents in Korea $(\%)$

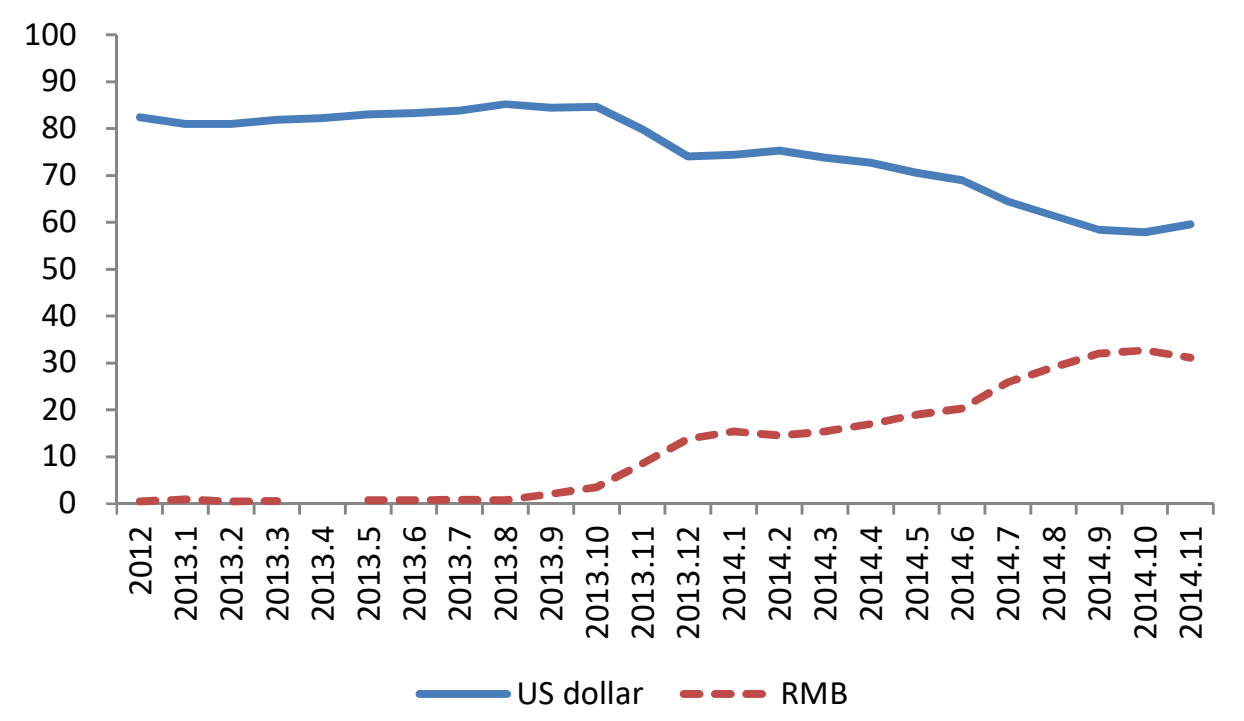

Source: The Bank of Korea

Note: The data for the RMB in April 2013 is missing.

The significance of this recent rise in the volume of RMB deposits should not be exaggerated, however, as its sustainability remains quite doubtful. It has been driven 
largely by arbitrage opportunities arising from interest rate differentials between the Korean and the Chinese markets, and not by the indigenous accumulation of RMB in Korea. In other words, the recent growth in RMB use in the Korean financial sector has been based on unreliable factors.

In greater detail, significant interest rate differentials between Korea and China have emerged recently, in line with the easy monetary policy in the former country and the tight policy in the latter. For instance, the average annual deposit interest rate in Korea, which had been 3.8 percent in 2011 and 3.4 percent in 2012, fell below 3.0 percent from February 2013, remained at around 2.5 to 2.6 percent until June 2014, and then dropped further to stand at 2.2 percent in October 2014. The benchmark Chinese interest rate in contrast stayed above 6 percent for most of time between January 2011 and October 2014, and with the PBOC requiring banks to maintain loan-to-deposit ratios at 75 percent or below it has been difficult for them to raise funds in the Chinese markets.

This situation has provided lucrative opportunities for Chinese banks operating in Korea, as they have been able to enjoy substantial arbitrage profits by borrowing in Korea and lending in China, given their abilities to pay higher interest rates to Korean depositors than Korean banks and then lend at even higher rates in China. Indeed, Chinese banks have generally offered interest rates for RMB deposits about 0.5 to 1.0 percentage points higher than those offered by Korean banks for won deposits (Kwon, 2014). The increase in RMB deposits in Korea has thus in fact been led mostly by Chinese banks, which confirms that RMB internationalization can benefit Chinese financial institutions. This means at the same time, however, that even the dramatic rise in RMB deposits has failed to generate strong 
indigenous interests in the RMB business among Korea banks, as these deposits have been taken mostly by Chinese banks.

Even more tellingly, the increase in RMB deposits in Korea has not been related to any indigenous growth in RMB holdings in the country. Instead, Korean depositors, most of them institutional investors such as securities firms and insurance companies, have borrowed funds in won, exchanged them for dollars and then sold the dollars for RMB, expecting higher interest rate gains from Chinese banks under the low interest-rate environment in Korea (Kwon, 2014). In fact, the enduring extremely low level of RMB trade settlement implies a low accumulation of RMB in the country.

The recent increased use of the RMB in the Korean financial sector thus stands on a very fragile foundation. If arbitrage opportunities and related speculative motives disappear, RMB use in the country's financial sector is likely to wane. And in November 2014, when the PBOC lowered the interest rate, arbitrage opportunities shrank and the amount of RMB deposits in Korea did indeed fall significantly, from USD 21.7 billion the previous month to USD 19.8 billion. At that time the share in total foreign currency deposits accounted for by the RMB also reversed to a decline, from its upward trend of the previous year.

\section{Politics of RMB internationalization}

In contrast to the situation in the markets, however, the Korean government has recently provided strong political boost for stimulation of RMB use in the country. It has implemented essential infrastructures for the promotion of RMB use, and also adopted 
various significant policy measures that have helped to generate new vested domestic interests supporting greater use of the currency.

\section{Initiative from the government}

As analyzed above, domestic firms and financial institutions have shown limited interest in facilitating RMB use in Korea. Likewise, the Korean government had also not adopted any specific policy in accord with the contemporary trend of RMB internationalization until late 2013, with the currency never having become an important policy issue in government circles. ${ }^{15}$ As a growing number of countries had intensified their endeavors to establish offshore RMB centers, ${ }^{16}$ however, the Korean government began to change its policy from early 2014, even in the absence of strong demand from its private sector. And on July 3 , 2014, during Chinese President Xi Jinping's first state visit to Korea, the Korean government finally announced a vision for developing the country into an offshore RMB center, entering into agreements with China on five specific measures to this end.

The five measures are as follow. First, it was agreed to open a direct trading market for the won and the RMB in Korea, while the conditions for creating another in China were to

\footnotetext{
${ }^{15}$ Author interviews with an anonymous MOSF official, September 13, 2013, by telephone; and with an anonymous BOK official, September 9, 2013, Seoul.

${ }^{16}$ In addition to Hong Kong, London, Singapore and Taiwan, major European countries such as France, Germany and Luxembourg have also joined the global race to become offshore RMB centers since early 2014.
} 
be fostered as well. ${ }^{17}$ Second, a Chinese bank operating in Korea was to be designated as the RMB clearing bank in the country. ${ }^{18}$ Third, Korea was awarded an RMB 80 billion quota for the Renminbi Qualified Foreign Institutional Investor (RQFII) program, which allows foreign investors to invest in mainland equities and bonds using offshore RMB. ${ }^{19}$ Fourth, the two countries agreed to increased investment in the Chinese markets by Korean authorities and financial institutions through the QFII program. ${ }^{20}$ Fifth, it was also agreed to encourage the issuance of RMB-denominated bonds in Korea, by financial institutions and non-financial firms from Korea and foreign countries including China. ${ }^{21}$

In the medium to long term, the government plans to expand the share of Korea-China trade settled in the RMB to beyond 20 percent — which will mean the settlement in RMB of about one-half of Korea-China trade having final destinations in either of the two

${ }^{17}$ Offshore trading of the won is currently prohibited, which was one reason why the won-RMB direct trading market was opened in Korea first.

${ }^{18}$ An offshore RMB clearing bank provides the clearing services for RMB transactions outside China through its connection with the China National Advanced Payment System of the PBOC. It administers the accounts of the banks participating in its clearing system and also offers RMB liquidity, thus operating in practice as an offshore branch of the PBOC.

${ }^{19}$ RQFII is expected to strengthen the incentives for holding RMB by expanding RMB investment opportunities, which may in turn help to increase RMB use for trade settlement, accordingly vitalizing the won-RMB direct trading market as well.

\footnotetext{
${ }^{20}$ A hike in the QFII quota increases investment opportunities in the Chinese financial markets.

${ }^{21}$ Chinese firms at present need permission from the Chinese authorities in order to issue RMB-denominated bonds in a foreign country, while the issuance of RMB-denominated bonds within China (so-called "panda bonds") is allowed for international financial organizations only.
} 
countries - and to increase the volume of RMB financial products such as bonds, derivatives and deposits to the third largest in the world (MOSF, 2014b).

The Korean government has two ultimate goals that it wishes to achieve through the establishment of an RMB hub: to maximize the economic gains from "China opportunities" and to strengthen the stability of the Korean economy (MOSF, 2014a). First, the government perceives China as an "opportunity," and expects to preoccupy the Chinese markets and also to revitalize the Korean economy through establishment of an offshore RMB hub (together with the recently signed Korea-China FTA) (Choi, 2014b; MOSF, 2014c). ${ }^{22}$ In detail, the building of an offshore RMB center is expected to reduce the transaction costs of Korean business with China, ${ }^{23}$ accordingly boosting the bilateral trade and overall interchanges with the country. The creation of an RMB hub is also expected to be a turning point for upgrading of the Korean financial industry by generating new business opportunities such as RMB trade finance and RMB lending (MOSF, 2014d). Meanwhile, the government also judges that the reduction of the country's reliance on the dollar through the diversification of settlement currencies will enhance the stability of its economy (MOSF, 2014a).

\footnotetext{
${ }^{22}$ The Korean government also wishes to claim establishment of an RMB hub as a successful case exemplifying the "Creative Economy" (Choi, 2014b: 3), a new economic paradigm presented by the current Park administration.

${ }^{23}$ For instance, direct won-RMB trading can reduce exchange commissions as the dollar is no longer necessary as an intermediary currency. The establishment of an RMB clearing bank also reduces the costs of settlement for RMB transactions, as RMB settlement is then possible without having to go through Hong Kong (MOSF, 2014d).
} 
This top-down approach in Korea in its attempt to build an RMB hub is in fact distinctive, contrasting as it does to the bottom-up approaches in most other economies in the global race to establish offshore RMB centers. Most of them-including Hong Kong, the United Kingdom, Singapore, Germany, France and Luxembourg — do in fact have global or regional finance centers. ${ }^{24}$ Many large financial institutions operating in these economies tend to have strong global competitiveness and accordingly keen interest in preoccupying the potentially lucrative RMB markets, and have in fact strongly demanded that their governments facilitate RMB use in their countries (Hornby and Jenkins, 2013; Muk, 2013; Song, 2013). The Korean case demonstrates in contrast that such strong demand from the private sector is not always a necessary condition for a government's promotion of RMB use in its country. A government can itself take the voluntary initiative for this, in the expectation of its benefiting the overall economy, in other words increasing the "national interest."

The Korean top-down approach has been fairly effective for establishment of the infrastructures necessary to stimulate RMB use, even ahead of any meaningful development of an RMB market. For example, the RMB clearing bank began offering its services in early November 2014. The direct trading market for the won and the RMB was meanwhile launched at the beginning of December that year, making Korea the third country, after Russia and Japan, to have opened a local currency-RMB direct trading market in its jurisdiction. ${ }^{25}$ As a result, although Korea is the latest comer in the global

\footnotetext{
${ }^{24}$ Taiwan meanwhile has a peculiar political relationship with China, in addition to their close economic ties.

${ }^{25}$ Russia and Japan opened their markets in December 2010 and June 2012 respectively.
} 
competition to build offshore RMB centers, it is now at the very forefront in terms of establishment of the essential infrastructures, as only it and the United Kingdom have all of the four requirements of a local currency-RMB direct trading market, an RMB clearing bank, an RQFII quota and a bilateral local currency swap arrangement with China.

\section{Creation of new domestic vested interests}

Introduction of the infrastructures necessary for RMB hub establishment does not of course ensure its realization. For this, among other factors, there will also need to be domestic private actors strongly supportive of RMB use. And in this regard the Korean case also illustrates how the government can effectively create new domestic vested interests related to RMB internationalization, by generating through its policy measures novel incentives for their increased use of the RMB.

Korea's participation in the RQFII scheme, for instance, has granted Korean financial institutions — including asset management companies but also banks, securities firms and insurance companies - access to Chinese equities and bonds through the use of offshore RMB. ${ }^{26}$ The Korean government has moreover agreed with its Chinese counterpart to allow

\footnotetext{
${ }^{26}$ The Chinese government usually grants RQFII quotas mostly to asset management companies, but has agreed with its Korean counterpart to expand Korean participation in the RQFII program to include banks, securities firms and insurance companies as well. Korea's participation in the RQFII scheme may also induce overseas RMB funds to flow into the country from countries not having RQFII quotas, which can benefit Korean financial institutions with those quotas.
} 
Korean banks to enter the CIBM, which accounts for 88 percent of the total value of bond trading in China and also provides yields about 1 percentage point higher than the Korean bond market (Kim and Ahn, 2014). ${ }^{27}$ The government plans in addition to increase the ceiling on the share of Chinese government bonds in publicly offered funds, from 10 to 30 percent, and to permit securities companies to engage in foreign exchange lending and foreign exchange repurchase agreement trading. The range of financial institutions that can do business with the RMB clearing bank is to be expanded as well, to include securities companies. All of these measures are expected to strengthen Korean financial institutions' interest in the RMB business by providing them new profit opportunities.

The permission for issuance of RMB bonds may also promote trading of other RMB financial products such as RMB stocks and derivatives, by heightening the incentives for holding RMB through the expansion of RMB investment opportunities. The government in fact even plans to issue RMB-denominated Foreign Exchange Stabilization Bonds, which also means an increase in the share of the RMB in the country's foreign exchange reserves (MOSF, 2014b). To increase RMB investment opportunities further, it also has a plan for creation of a private equity market for institutional investors investing in RMB assets. ${ }^{28}$ Meanwhile, the establishment of the RMB clearing bank is expected to help with the accumulation of RMB in the country by reducing Korean financial institutions' need for

\footnotetext{
${ }^{27}$ China permits foreign central banks and foreign commercial banks engaging in the RMB trade settlement business to participate in the CIBM.

${ }^{28}$ The government also plans to apply for an increase in the QFII quotas of public agencies such as Korea Investment Corporation and the National Pension Service (MOSF, 2014b).
} 
holding RMB for settlement purposes in foreign offshore RMB centers such as Hong Kong (MOSF, 2014b). All of these measures are also expected to generate various new RMB business opportunities for domestic financial institutions.

Although it is still too early for firm assessment, there are some notable early positive signs of favorable responses by Korean financial institutions to these government initiatives to facilitate RMB use in the country. In early October 2014, for example, Woori Bank became the first Korean bank to issue RMB bonds (worth RMB 200 million). A number of Korean financial institutions, including asset management companies, securities companies, banks and insurance companies, have submitted or planned applications for RQFII quotas, competing to launch RQFII products earlier than each other (FSC, 2014). A majority of major domestic commercial banks have also joined the competition to attract RMB deposits, launching new RMB deposit products offering interest rates higher than those for won deposits. In fact, after the government's adoption of its plan to establish an RMB hub the total volume of RMB deposits at five major Korean banks increased significantly, from USD 123 million in July to about USD 140 billion in October 2014 (Choi, 2014a). Major banks have also acquired permissions to enter the CIBM or are preparing to do so. The first RMB loan product in Korea was launched as well, in early December 2014.

Won-RMB direct trading is meanwhile widely assessed as having enjoyed a successful start, since it averaged a volume of RMB 5.4 billion (about USD 880 million) per day in the first one month after the market opened, equivalent to about 13 percent of average daily won-dollar trading and also more than four times the average daily volume in the yen-RMB direct trading market in Tokyo (Lee, 2014a; MOSF, 2015). In order to help create demand 
for and supply of RMB the Korean government has designated 12 banks as market makers, to lead trade pricing by disclosing sale and purchase prices and also provide liquidity, and the majority of won-RMB trading during this initial period was done by these banks out of intentions to predominate the market or to maintain their statuses as market makers (Lee, 2014a; MOSF, 2015). This encouraging start of the won-RMB direct trading market is thus also attributable largely to the strengthened private interest in its success owing to the active government policy to facilitate RMB use in the country.

\section{Conclusion}

As RMB internationalization has enjoyed an impressive start, the research on it has also grown considerably in recent years. However, while the supply side of the RMB internationalization issue has been addressed to a substantial extent, the demand side remains significantly underexplored. Such a bias in favor of supply-side analysis has in fact been common in the study of other international currencies as well, and so is not limited particularly to that of the RMB. In addition, when assessing the global level of RMB internationalization much of the research has focused mainly on use of the RMB at the aggregate global level or that in Hong Kong, while neglecting that in ordinary foreign economies even though the growth in use in those economies is crucial to the ultimate success of RMB internationalization. This study has attempted to fill these important gaps in the literature by providing an in-depth analysis of the use of the RMB in Korea, an ordinary foreign economy, from both an economic and a political perspective. 
With regard to the economics of RMB internationalization, this research has found that sustainable indigenous market forces favorable to RMB use remain weak in Korea, despite China's enthusiastic attempts to promote RMB internationalization over the recent few years as well as the strong potential in Korea for growing RMB use. Although use of the RMB in the Korean financial sector has recently grown substantially, that has been due mainly to speculative motives, an unreliable base for persistent RMB use, and has not been associated with any indigenous buildup of RMB holdings in the country. Regarding the politics of RMB internationalization, however, this study has also clearly illustrated that political factors can have significant impacts on RMB use in a country, and largely positive ones in the specific case of Korea. In that country, the main initiative for the boosting of RMB use has originated from the government itself, which has implemented the major infrastructures necessary for stimulation of RMB use, even in the absence of strong demand for this from the private sector. Even more tellingly, the government has through its policy measures been able to encourage the emergence of new domestic vested interests supporting RMB internationalization, especially in the financial sector, by offering them opportunities to profit from growing RMB use.

These findings together ultimately suggest that politics in foreign economies-along with market forces and economic and political conditions in China itself-do matter for the future of RMB internationalization. Especially in this early stage of RMB internationalization, the intrinsic economic attractiveness of the RMB as an international currency remains quite weak, in particular compared with the dollar, the current dominant international currency. In this situation, in order for RMB internationalization to take off 
successfully, policy support from the governments of foreign countries, as well as from the Chinese government itself, appears to be crucial, particularly in the case of ordinary foreign countries having neither special political relationships with China nor global financial centers. These findings are expected to offer a valuable stepping stone for additional development of the study of RMB internationalization and, going further, of currency internationalization in general. They may also provide significant policy implications for China with regard to its future strategy for further stimulation of RMB internationalization.

\section{References}

BOK and MOSF (Bank of Korea and Ministry of Strategy and Finance), 2012,

"Introduction of a System for Use of the Korea-China Currency Swaps for Trade Settlement," press release, December 4, Seoul. (In Korean).

Campanella, M., 2014, "The Internationalization of the Renminbi and the Rise of a Multipolar Currency System," ECIPE Working Paper No. 01/2014, European Centre for International Political Economy, Belgium.

Chen, X. and Y.-W. Cheung, 2011, "Renminbi Going Global," China \& World Economy, Vol. 19, No. 2, pp. 1-18.

Chey, H.-k., 2012, "Theories of International Currencies and the Future of the World Monetary Order," International Studies Review, Vol. 14, No. 1, pp. 51-77.

Chey, H.-k., 2013, "Can the Renminbi Rise as a Global Currency? The Political Economy of Currency Internationalization," Asian Survey, Vol. 53, No. 2, pp. 348-68. 
Chey, H.-k., 2014, "The Political Economy of Currency Internationalization," in T. Oatley and W. K. Winecoff, eds, Handbook of the International Political Economy of Monetary Relations, pp. 39-53. Cheltenham and Northampton: Edward Elgar Publishing.

Chinn, M. and J. A. Frankel, 2008, "Why the Euro Will Rival the Dollar," International Finance, Vol. 11, No. 1, pp. 49-73.

Choi, H., 2014a, "Strategies for RMB Deposits," Economy Plus, November, No. 120. (In Korean).

Choi, K. H., 2014b, "Words of Encouragement from Deputy Prime Minister at the Opening of the Won/RMB Direct Trading Market)," December 1, Seoul. (In Korean).

Cohen, B. J., 2012, "The Yuan Tomorrow? Evaluating China's Internationalisation Strategy," New Political Economy, Vol. 17, No. 3, pp. 361-71.

Cohen, B. J., 2014, "Will History Repeat Itself? Lessons for the Yuan," ADBI Working Paper Series No. 453, Asian Development Bank Institute, Tokyo.

Dobson, W. and P. R. Masson, 2009, "Will the Renminbi Become a World Currency?" China Economic Review, Vol. 20, No. 1, pp. 124-35.

Eichengreen, B., 2013, "Number One Country, Number One Currency," The World Economy, Vol. 36, No. 4, pp. 363-74.

Eichengreen, B. and M. Kawai, 2014, "Issues for Renminbi Internationalization: An Overview," ADBI Working Paper No. 454, Asian Development Bank Institute, Tokyo. 
Euromoney, 2013, "China RMB Debate: The Renminbi's Road to Full Internationalization," July.

FSC (Financial Services Commission), 2014, "The Work of the Task Force for RQFII," press release, September 29, Seoul. (In Korean).

Frankel, J. and S.-J. Wei, 1994, "Yen Bloc or Dollar Bloc," in T. Ito and A. O. Krueger, eds, Macroeconomic Linkages: Savings, Exchange Rates and Capital Flows, pp. 295355. Chicago: University of Chicago Press.

Fratzscher, M. and A. Mehl, 2011, "China's Dominance Hypothesis and the Emergence of A Tri-polar Global Currency System," ECB Working Paper No. 1392, European Central Bank, Frankfurt.

Helleiner, E. and A. Malkin, 2012, "Sectoral Interests and Global Money: Renminbi, Dollars and the Domestic Foundations of International Currency Policy," Open Economies Review, Vol. 23, No. 1, pp. 33-55.

Hornby, L. and P. Jenkins, 2013, "Chancellor George Osborne Cements London as Renminbi Hub." Financial Times, October 15, London.

Ito, T., 2010, "China as Number One: How about the Renminbi?," Asian Economic Policy Review, Vol. 5, No. 2, pp. 249-76.

Kawai, M. and V. Pontines, 2014, "Is There Really a Renminbi Bloc in Asia?," ADBI Working Paper Series No. 467, Asian Development Bank Institute, Tokyo.

Kim, K. and J. Ahn, 2014, "First Issuance of RMB Bonds - Acceleration of Building Up of RMB Hub," MK News, October 9, Seoul. (In Korean). 
Kirshner, J., 2014, "Regional Hegemony and an Emerging RMB Zone," in E. Helleiner and J. Kirshner, eds, The Great Wall of Money, pp. 213-40. Ithaca and London: Cornell University Press.

Kwon, D., 2014, "Drastic Increase in RMB Deposits in July - New Record High Volume of Foreign Currency Desposits," MoneyToday, August 8, Seoul. (In Korean).

Lee, H., 2014a, "First One Month of Won-RMB Direct Trading Market Has Been A 'Half Success'," Hankookilbo, December 30, Seoul. (In Korean).

Lee, J.-W., 2014b, "Will the Renminbi Emerge as an International Reserve Currency?," The World Economy, Vol. 37, No. 1, pp. 42-62.

Lee, S., 2012, "41\% of Chinese Firms Say 'We Will Offer 3\% Discount for Renminbi Trade Settlement."' Asian Economy, October 21, Seoul. (In Korean).

Liao, S. and D. E. McDowell, forthcoming, "Redback Rising: China's Bilateral Swap Agreements and Renminbi Internationalization," International Studies Quarterly.

Mallaby, S. and O. Wethington, 2012, "The Future of the Yuan: China's Struggle to Internationalize Its Currency," Foreign Affairs, Vol. 91, No. 1, pp. 135-46.

MOSF (Ministry of Strategy and Finance), 2013, "First Renimnbi Loans through the Korea-China Currency Swap Provided to Support Trade Settlement," press release, January 28, Seoul. (In Korean).

MOSF, 2014a, "Q\&As on the Korea-China Agreements on Promotion of the Use of the RMB," press release, July 3, Seoul. (In Korean).

MOSF, 2014b, "Measures for the Stimulation of RMB Transactions in Order to Grow to An RMB Financial Center," press release, October 31, Seoul. (In Korean). 
MOSF, 2014c, "Words of Encouragement by Deputy Prime Minister Choi Kyung Hwan at the Opening of the Won/RMB Direct Trading Market," press release, December 1, Seoul. (In Korean).

MOSF, 2014d, "Major Agreements Related with the Enhancing of RMB Use at the KoreaChina Summit, and Their Meanings," press release, July 3, Seoul. (In Korean).

MOSF, 2015, "Assessment of Won-RMB Direct Trading Market One Month After Opening," press release, January 7, Seoul. (In Korean).

Muk, E., 2013, "Singapore to Get Rmb50 Billion of RQFII Quota," AsianInvestor, October, 23, Hong Kong.

Park, Y. C., 2010, "RMB Internationalization and Its Implications for Financial and Monetary Cooperation in East Asia," China \& World Economy, Vol. 18, No. 2, pp. $1-21$.

Price, S., 2014, "RMB Internationalisation Talk 'Overblown'." AsianInvestor, November 6, Hong Kong.

Song, J., 2013, "Taiwan Nears Formosa Bonds Landmark." FinanceAsia, December 4, Hong Kong.

Subacchi, P., 2013, "Expanding Beyond Borders: The Yen and the Yuan," ADBI Working Paper Series No. 450, Asian Development Bank Institute, Tokyo.

Subramanian, A., 2011a, Eclipse: Living in the Shadow of China's Economic Dominance, Washington, D.C.: Perterson Institute for International Economics. 
Subramanian, A., 2011b, "Renminbi Rules: The Conditional Imminence of the Reserve Currency Transition," Working Paper WP 11-14, Peterson Institute for International Economics, Washington, D.C.

Subramanian, A. and M. Kessler, 2012, "The Renminbi Bloc Is Here: Asia Down, Rest of the World to Go?," Working Paper WP 12-19, Peterson Institute for International Economics, Washington, D.C.

SWIFT, 2014, "RMB Breaks into the Top Ten Most-used Currencies for Payments," available at $<$ http://www.swift.com/assets/swift_com/documents/products_services/RMB_track er_January2014_final_sdc.pdf> (accessed October 10, 2014).

Wu, F., R. Pan and D. Wang, 2010, "Renminbi's Potential to Become a Global Currency," China \& World Economy, Vol. 18, No. 1, pp. 63-81.

Yu, Y., 2014, "How Far Can Renminbi Internationalization Go?," ADBI Working Paper Series No. 461, Asian Development Bank Institute, Tokyo. 